\title{
Temperature requirements for growth and ripening of apples*
}

\section{H. G. Kronenberg}

Department of Horticulture, Wageningen Agricultural University, P.O. Box 30, NL 6700 AA Wageningen, Netherlands

Received 4 May 1987; accepted 7 August 1987

Key words: apple, temperature requirement, modelling, fruit growth period

\begin{abstract}
With a rather simple model the influences of temperatures on the growth and ripening of up to ten apple cultivars in four places in Europe was studied. Reactions on prevailing temperatures were found and could roughly be divided in three influence periods. In most cases the first month after the beginning of the flowering and the period before the moment of picking showed a positive reaction towards high temperatures. During the period in between, which differed from 1-2 months in early cultivars to 5-6 months in late ones, no temperature influences at all were found in most cultivars. The nearer the north border of apple ripening potentials, the better the model fitted. Temperature sums found in the first and third reaction periods did not show any relationship with earliness or lateness of crops. On the contrary, early and late cultivars might have about the same sums. Introduction of base monthly temperatures took away from 0 up to $89 \%$ of the differences in days between the several periods that an apple grows on a tree.
\end{abstract}

\section{Introduction}

Kronenberg (1983) described a first period of reaction of the apple tree to environmental conditions. A second aim of research formed the period that apples grow on the trees. In this period, relationships between environmental conditions and the apple tree are, however, much more complicated. All growth regulating factors e.g. irradiation, temperature, rainfall, wind, etc. may have influences and interactions between certain factors are likely. An analysis therefore will be difficult. There seems to be a good relationship between yield per tree and total short-wave radiant energy (Landsberg, 1979).

* Publication 530, Department of Horticulture, Wageningen Agricultural University, Netherlands. 
Research into apple tree-temperature relationships is a rather underdeveloped part of fruit growing. General information on this subject is vague and found only in handbooks on fruit growing (Sprenger, 1948; Winter, 1981). The only remarks are that high(er) temperature during the summer are favourable for the growth of fruits and that certain cultivars need more warmth in the season than others. 'Jonathan' and 'Golden Delicious' are hardly recommendable apples in the northern parts of Europe. 'Granny Smith' grows only well if temperatures are high enough.

A much more promising path is not to look for general relationships but for more specific ones. In the research reported here, the relationships are studied between prevailing temperatures and the period that the apples are hanging on the trees. A point can be raised here: what is more important, information on the possibilities of fruit becoming pick-ripe or of tree growth. As apple trees are grown to produce a harvest, this fact is more relevant. Therefore, information on the influences on fruit growth and ripening is considered of primary importance.

On the influences of temperature during this period, information is contradictory. It was stated that there is no influence of the weather during the period that apples grow on the trees. Blanpied (1960) however, showed a significant correlation for McIntosh apples of $r=+0.76$ between summation of daily maximum temperature over $7.2^{\circ} \mathrm{C}$ and days from bloom to harvest (10 years). Fisher (1962) used heat units, which were calculated as day-degrees for the period elapsing between bloom and harvest on the basis of

$\frac{\text { daily maximum temperature }\left({ }^{\circ} \mathrm{C}\right)+\text { daily minimum temperature }\left({ }^{\circ} \mathrm{C}\right)}{2}-10($

The base temperature of $10{ }^{\circ} \mathrm{C}$ was arbitrarily chosen. Silbereisen (1970), quoted in Winter (1981), found a positive correlation between yield and temperature sums over $10{ }^{\circ} \mathrm{C}$ during the season. Beattie \& Folley (1978) reported that the mean maximum temperature in June had great influences on the yield of 'Worcester Pearmain' and 'Cox's Orange Pippin'. Jackson \& Hamer (1980) found that high temperatures immediately after full bloom were associated with high yields; cold weather in June, however, with low yields. Winter (1981) stated that temperatures below $9{ }^{\circ} \mathrm{C}$ form the end of the apple growth period. It can be concluded that the literature cited clearly indicates that the temperature is important during the growth period of apples; base temperatures may be found which are higher than those found earlier during spring (Kronenberg, 1983).

An apple tree with fruits on it can be considered as a system: a limited part of reality that contains interrelated elements. A model is a simplified representation of a system and simulating may be defined as the art of building a mathematical model and the study of its properties in relation to those of the system. Therefore a model will never completely explain a system. If say $50 \%$ is explained, an enormous gain is made. In the present research the same model is used as by Kronenberg (1983). 


\section{Materials and methods}

\section{Data used}

In several places, dates of flowering and picking are compiled, but this has been done over such a long period that the data seemed useful in this research in few places only. To obtain an insight into the temperature requirements, a broad selection of cultivars and a certain selection of countries (places) were desirable, while certain cultivars had to be grown on several places. Therefore four places (fruit growing stations) were selected (Table 1). Not all four meteorological stations that were nearest to the fruit growing stations could provide the same information. Three different climatic data had to be used. These differ only very slightly over the year and the years (personal communication KNMI, De Bilt, the Netherlands) and will not interfere with the results. The most ideal situation of a meteorological station quite near the observation orchard was infeasible. There was, however, always a certain distance between meteorological station and orchard. The longest distance was $40 \mathrm{~km}$, but it is known that temperature differences between De Bilt and Wageningen are negligible. In all other cases distances are much smaller. A correction had to be made for Bavendorf, $490 \mathrm{~m}$ above sea level, and Friedrichshaven, $410 \mathrm{~m}$ above sea level. It was accepted that temperatures at Bavendorf were $0.5^{\circ} \mathrm{C}$ lower than those in Friedrichshafen.

Table 1. Meteorological data.

\begin{tabular}{|c|c|c|c|}
\hline $\begin{array}{l}\text { Place of apple } \\
\text { observations }\end{array}$ & $\begin{array}{l}\text { Meteorological } \\
\text { station }\end{array}$ & $\begin{array}{l}\text { Estimated distance } \\
\text { between place of } \\
\text { observation and met. station }\end{array}$ & $\begin{array}{l}\text { Mean daily } \\
\text { temperature } \\
\text { is based on }\end{array}$ \\
\hline $\begin{array}{l}\text { Blangstedgaard } \\
\left(55^{\circ} 40^{\prime} \text { north, }\right. \\
\left.10^{\circ} 40^{\prime} \text { east }\right) \\
\text { Denmark }\end{array}$ & $\begin{array}{l}\text { Beldringe airport } \\
\text { Odense }\end{array}$ & $5 \mathrm{~km}$ & $\begin{array}{l}\text { (minimum }+ \\
\text { maximum }): 2\end{array}$ \\
\hline $\begin{array}{l}\text { Wageningen } \\
\left(52^{\circ} \text { north, }\right. \\
\left.5^{\circ} 20^{\prime} \text { east }\right) \\
\text { Netherlands }\end{array}$ & $\begin{array}{l}\text { Koninklijk Nederlands } \\
\text { Meteorologisch Instituut } \\
\text { Main station De Bilt }\end{array}$ & $40 \mathrm{~km}$ & $\begin{array}{l}24 \text { hourly } \\
\text { observation }\end{array}$ \\
\hline $\begin{array}{l}\text { Wilhelminadorp } \\
\left(51^{\circ} 30^{\prime} \text { north, }\right. \\
3^{\circ} 46^{\prime} \text { east) } \\
\text { Netherlands }\end{array}$ & $\begin{array}{l}\text { Koninklijk Nederlands } \\
\text { Meteorologisch Instituut } \\
\text { Station Vlissingen }\end{array}$ & $20 \mathrm{~km}$ & $\begin{array}{l}24 \text { hourly ". } \\
\text { observations }\end{array}$ \\
\hline $\begin{array}{l}\text { Bavendorf } \\
\left(47^{\circ} 45^{\prime} \text { north, }\right. \\
\left.9^{\circ} 40^{\prime} \text { east }\right) \\
\text { Federal Republic } \\
\text { of Germany }\end{array}$ & $\begin{array}{l}\text { Climatical Station } \\
\text { Friedrichshafen }\end{array}$ & $10 \mathrm{~km}$ & $\begin{array}{l}3 \text { registrations: } \\
7,14,21 \mathrm{~h} \\
\text { (mean local } \\
\text { time) }\end{array}$ \\
\hline
\end{tabular}


Table 2 gives all data used. Not all experimental stations registrated the moment of the beginning of flowering in the same way. Blangstedgaard registrated $20 \%$ open flowers; Wageningen $20 \%$ too, but from 1973 on upwards $0 \%$ and full flowering (petal fall) were registrated. These figures therefore are corrected with 1 day: the $0 \%$ moment +1 day gives the $20 \%$ moment. Wilhelminadorp gives the $20 \%$ open flowers moment, but Bavendorf registrated $80 \%$ flowers open. Here the $20 \%$ moment was found by deducting 3 days. This made all figures comparable.

Table 2. Data on flowering and picking of apples (cultivars in order from early to late).

\begin{tabular}{|c|c|c|c|}
\hline Cultivar & Place & Years & $\begin{array}{l}\text { Number } \\
\text { of } \\
\text { years }\end{array}$ \\
\hline White Transparent & \multirow[t]{4}{*}{ Blangstedgaard } & 1961-1966 (1965 missing) & 5 \\
\hline Cox's Orange Pippin & & $\begin{array}{r}1960-1976 \text { (1967, 1968, 1969, } \\
1974,1975 \text { missing) }\end{array}$ & 12 \\
\hline Ingrid Marie & & $\begin{array}{c}1961-1970(1965,1967,1968 \\
1969 \text { missing })\end{array}$ & 6 \\
\hline Golden Delicious & & $\begin{array}{r}1960-1976(1962,1967,1968 \\
1969,1975 \text { missing })\end{array}$ & 12 \\
\hline White Transparent & \multirow[t]{7}{*}{ Wageningen } & 1927-1947 (1944, 1945 missing) & 18 \\
\hline Cox's Orange Pippin & & $1973-1985$ & 13 \\
\hline Lombarts Calville & & $1980-1983$ & 4 \\
\hline \multirow[t]{2}{*}{ Schone van Boskoop } & & $1927-1948$ (1944, 1945 missing) & \\
\hline & & 1973-1984 (1974 missing) & 30 \\
\hline Jonathan & & 1975-1979 (1977 missing) & 4 \\
\hline Golden Delicious & & $1973-1985$ & 13 \\
\hline White Transparent & \multirow[t]{10}{*}{ Wilhelminadorp } & $1971-1976$ & 6 \\
\hline James Grieve & & $1971-1983$ & 13 \\
\hline Cox’s Orange Pippin & & $1971-1983$ & 13 \\
\hline Lombarts Calville & & $1977,1982,1983$ & 3 \\
\hline Schone van Boskoop & & 1953-1983 (1959 missing) & 30 \\
\hline Jonathan & & $1971-1983$ & 13 \\
\hline Golden Delicious & & $1971-1983$ & 13 \\
\hline Jonagold & & $1971-1983$ & 13 \\
\hline Gloster & & 1971-1983 & 13 \\
\hline Granny Smith & & $1971-1975$ & 5 \\
\hline James Grieve & \multirow[t]{8}{*}{ Bavendorf } & 1964-1980 (1965 missing) & 16 \\
\hline Cox's Orange Pippin & & $1964-1980$ & 17 \\
\hline Schone van Boskoop & & $1964-1980$ & 17 \\
\hline Jonathan & & $1964-1980$ & 17 \\
\hline Golden Delicious & & $1964-1980$ & 17 \\
\hline Jonagold & & 1974-1980 (1977 missing) & 6 \\
\hline Gloster & & $1972-1980$ & 9 \\
\hline Granny Smith & & $1971-1980$ & 10 \\
\hline
\end{tabular}




\section{Model applied}

The model used was the same as in Kronenberg (1983). Each day after the beginning of flowering contributes a quantity $\tau_{j}=t_{j}-b$ to the sum of temperatures, where $t_{j}$ stands for the mean daily temperature and $b$ for a base temperature. A daily temperature below $b$ does not contribute. As soon as the sum of daily temperatures in a year exceeds a quantity $T$ (the needed sum of temperatures) the apple ripens. In equation:

$$
T+\varepsilon_{i}=\sum_{j=1}^{J_{i}} \tau_{i j}
$$

where:

$T=$ needed temperature sum

$\tau_{i j}=t_{i j}-b\left(\right.$ if $t_{i j} \geqq b ; \tau_{i j}=0$ if $t_{i j}<b$ )

$t_{i j}=$ mean daily temperature, year $i$, day $j$ (counted from beginning of flowering)

$b=$ base temperature

$J_{i}=$ day of ripening (counted from the blossoming day), year i (stochastic variable)

$\varepsilon_{i}=$ random component (due to other influences).

The parameters to be estimated were the base temperature $b$ and the needed sum of temperatures $T$; the dates of blossoming and ripening $\left(J_{i}\right)$ were observed (dependent, explained variable). The explanatory or independent variables were the mean daily temperature $\left(t_{i j}\right)$.

The model became more complicated when we introduced different base temperatures; we assumed the base temperature constant for a month. For simplicity, only one temperature $(b)$ was used below. It is easy to generalize to 8 temperatures $\left(b_{1}\right.$, $b_{2}, b_{3}, b_{4}, b_{5}, b_{6}, b_{7}$ and $b_{8}$ ).

Given the model, the problem was to find the best estimates of parameters. Therefore a criterion to measure the goodness of fit of an estimate was needed.

Define:

$$
\hat{J}_{i}=\min _{k}\left\{J_{k}: T \leqq \sum_{j=1}^{J_{k}} \tau_{i j}\right\} \text { (expected day of ripening, given } b \text { and } T \text { ) }
$$

in which $k$ is the number of days (counted from blossoming)

$$
\begin{aligned}
& d_{i}=J_{i}-\hat{J}_{i} \\
& D^{2}=\sum_{i=1}^{n} d_{i}^{2} \quad(n=\text { number of years }) \\
& \bar{D}^{2}=\frac{1}{n} D^{2}=\frac{1}{n} \sum_{i=1}^{n}\left(J_{i}-\hat{J}_{i}\right)^{2}
\end{aligned}
$$

So $d_{i}$ is the difference between the observed day of ripening and the expected day, given $b$ and $T$. $D^{2}$ can be used to measure the goodness of fit of estimates (the smaller $D^{2}$, the better the estimates). To minimize $\bar{D}^{2}$ we are not aware of any algorithm so we had to use a try-and-error method. 


\section{Method for minimizing $\bar{D}^{2}$}

The most secure way to find that combination of base temperatures that minimizes the value of $D^{2}$ is investigating all possible combinations of base temperatures. This is even for a computer a too big job. Therefore a computer program was written based on the following approximation.

1. Determine per month the mean base temperature. It is unlikely that the right combination of base temperatures is found that way, because there may be interdependences and a month is a rather arbitrary period of changing base temperature reactions of the plants. The so found series of base temperatures is used as a first indication.

2. Investigate possibilities of base temperatures that are 1 or $2{ }^{\circ} \mathrm{C}$ higher or lower than those found in (1). Now certain month-base temperatures will stay the same, others will change. In a second trial possibilities of a further changing of these base temperatures will be tried out, maybe even a third and a fourth trial will be necessary. On the moment that none of the base temperatures changes any more it is assumed that now that combination of base temperatures is found, that minimizes the value of $D^{2}$.

3. Finally all base temperature combinations which are no more than $2{ }^{\circ} \mathrm{C}$ away from the base found under (2) are investigated. Combinations with $D^{2}$ less than 1.02 times the minimum $D^{2}$ give an impression of the shape (flatness) of the minimum found.

It is still possible that the minimum found by the computer is a local minimum and not the absolute minimum of $D^{2}$ as a function of $b$, etc.

\section{Results and discussion}

Results of all calculations are given in Table 3. Before these results can be discussed, some comments have to be made on the data used. Data on flowering are quite exact, maybe there is a possibility of an individual interpretation of only one day. Data on picking are exact too, but the problem here is that the moment of picking is rather vague. Ripening of an apple is a process that takes time and therefore the moment of picking can be influenced by a number of circumstances. This problem is of more importance in later cultivars than in early ones. Suggested factors influencing the moment of picking are:

- The weather. Apples are only picked when dry. A rainy period can alter the moment with a couple of days.

- Frost expectations can push the picking to earlier dates specially of influence in late cultivars.

- Long sequences of years were used sometimes. In all these years the practice of fruit growing may have changed: earlier picking to get better possibilities for transport and keeping or later picking to produce riper fruit for the fresh market. In some cultivars, selective picking was a common practice but has become disused.

- A personal interpretation of the picking moment. In a long row of years, the person who picked the apples has changed certainly and maybe the moment of picking too. 


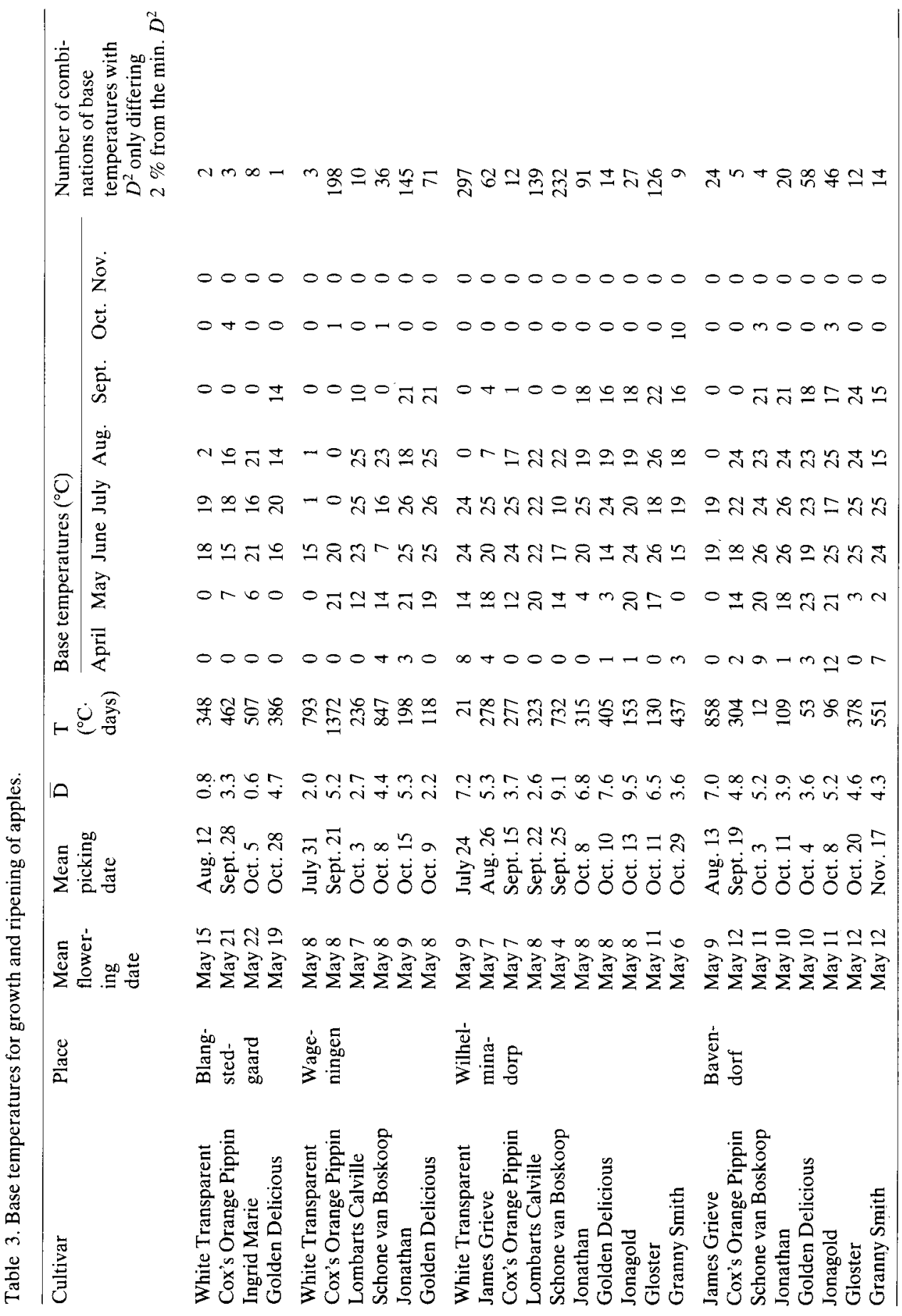

Netherlands Journal of Agricultural Science 36 (1988) 
The above-mentioned uncertainty of the registrated picking day has interfered with the results and may make conclusions rather vague, as shown in Table 4.

The model used gives results if applied to the period blossoming - picking. Base temperatures found hold only true in the processes that lengthen or shorten the period that apples grow on the trees. These base temperatures have - however - no connection with growth of trees, etc. Quite a lot of the base temperatures are rather high, in many cases so high that in such period prevailing temperatures have no influence on the period that apples hang on the tree. Therefore base temperatures in this period of the year are quite another conception than in spring.

The reported temperature sums over the whole period considered and with found base temperatures taken into account, differ from 12 to $1372^{\circ} \mathrm{C}$.days. An early cultivar can have a low value for the temperature sum ('White Transparent', Wilhelminadorp), but a late cultivar too ('Schone van Boskoop', Bavendorf). The highest temperature sum is found in the mid-season 'Cox's Orange Pippin' (Wageningen): $1372{ }^{\circ} \mathrm{C}$-days. A thesis that temperature sums give an indication for earliness of a cultivar is therefore incorrect. The calculations seldom lead to pronounced values of monthly base temperatures. The numbers of combination of base temperatures which are quite close to the best fit differ from 1 to 297 . This means that the likeliness of a minimum is quite real (1) or only one of the very many (297).

A general survey of all base temperatures shows a rise in the beginning of the season, a high mid-season value and a lowering value later in the season. In quite a lot of the cases, values of 0 were found. The high mid-season temperatures are frequently so high that a 'blocked period' with a length from 2-6 months is shown: a period that prevailing temperatures have no influence on the picking date at all. There is a difference between early and later cultivars. In early cultivars the 'blocked' period is shorter and the blocking is less absolute. It is suggested that the typical character of an early cultivar is that the 'blocked' period is short and long in later cultivars.

It seems possible to relate processes that happen in the apple to the above-mentioned general behaviour. Just after fertilization the young apple has a period of intensive activity. Cell division and plasma increase are important. Respiration is on a high level. This period lasts about 3 weeks (Wellensiek \& Doorenbos, 1956). In this period, base temperatures are low: the processes need all the heat there is; or: prevailing temperatures normally are too low to give full possibilities to the abovementioned processes. In the second phase, respiration is much lower. Starch is produced and growth of the apple is no longer by cell division but by cell elongation. These processes happen over rather a long period and prevailing temperatures are in most cases high enough, meaning that these temperatures have not much influ-

Table 4. Flowering and picking dates of 'Schone van Boskoop' (Wilhelminadorp).

\begin{tabular}{lll}
\hline Years & Mean flowering date & Mean picking date \\
$1953-1970$ & May 2 & October 9 \\
$1971-1983$ & May 4 & September 25 \\
\hline
\end{tabular}


ence. When this period is short, apples have a short period for accumulating starch: such apples have thin cell walls and little starch but sugar-containing cells. In the third phase starch is transformed into sugars and respiration is still rather low. The process of ripening of the fruits starts with a sudden rise in respiration. The chlorophyll vanishes and the fruits get a more yellowish (by carotenoids) or a more purple colour by the simultaneous synthesis of anthocyanins. In this period low base-temperatures are found. The data show that this third period lasts between 0 and 60 days. In early cultivars the above-mentioned periods are less clearly defined than in later ones.

There seems to be not a single temperature sum, but there are two: one in the first period (immediately after flowering) and another in the third period during the beginning of the ripening. An arbitrarily chosen example demonstrates this (Table 5).

The period that apples grow on the trees is more determined by the 'blocked' period than by the temperature sum. Early and late cultivars can have nearly the same temperature sum (see result for Blangstedgaard).

In comparing the results of the four places it is clear that $\bar{D}$ is rather low in Blangstedgaard, with an average value of 2.3. In the other places this average values are respectively $3.6,6.2$ and 4.8 . This means that the clearing-up power of the model is highest in Blangstedgaard near the border of the production possibilities for apples. More to the south, temperatures are less limiting and the value of $\bar{D}$ is higher. In Wilhelminadorp, in 4 cultivars (out of 10) the model did not work well. Therefore, results do not fit so well in this sequence.

Surveying the data of Table 3 it strikes that base temperatures in Blangstedgaard were lower than elsewhere, simply because prevailing temperatures were lower! The number of other nearly optimal proposals (last column of Table 3) is in Blangstedgaard rather low too (with an average of 3.5) which means that the given temperatures were very likely. This strengthens the idea of a good fitting of the model there.

This research was also designed and developed to get information on one cultivar in more than one place. It is, however, very difficult, in most cases even impossible, to find a common behaviour of a certain cultivar in 2-4 places. Results obtained were very inconsistent.

Table 5. Temperature sums in 'Lombarts Calville' (Wageningen).

\begin{tabular}{|c|c|c|c|c|c|c|c|c|c|}
\hline \multirow[t]{2}{*}{ Year } & \multirow{2}{*}{$\begin{array}{l}\text { Temperature } \\
\text { sum }\end{array}$} & \multicolumn{8}{|c|}{ Month } \\
\hline & & April & May & June & July & Aug. & Sept. & Oct. & Nov. \\
\hline 1980 & 224 & 0 & 42 & 0 & 0 & 0 & 158 & 24 & 0 \\
\hline 1981 & 222 & 10 & 76 & 0 & 0 & 0 & 136 & 0 & 0 \\
\hline 1982 & 297 & 0 & 68 & 0 & 0 & 0 & 168 & 62 & 0 \\
\hline 1983 & 241 & 0 & 5 & 1 & 1 & 0 & 126 & 107 & 0 \\
\hline Average & 246 & 2 & 48 & 1 & 1 & 0 & 147 & 48 & 0 \\
\hline
\end{tabular}




\section{Evaluation of the results}

It seems possible to evaluate (partly) the above reported results. As parameter to find the most probable base temperatures, $\bar{D}$ was chosen; as shown in Table 3 , there were quite different values of $\bar{D}$ per cultivar. Now, the question arises whether base temperatures for a cultivar with a low $\bar{D}$ value are more probable than those for a cultivar with a high value. This, however, seems an incorrect proposition. Not the value of $\bar{D}$ ought to be considered a standard, but the value of $\bar{D}$ $\left(\bar{D}_{\text {new }}\right)$ compared with the $\bar{D}\left(\bar{D}_{\text {old }}\right)$ of the original scattering of picking dates. Table 6 shows that introduction of base temperatures in the period between flowering and picking leads to lower values of $\bar{D}$ in 21 cases. In seven cases, negative improvement percentages are shown. In four cases, these negative improvements cor-

Table 6. Comparison between $\bar{D}_{\mathrm{o}}$ and $\bar{D}_{n}$ : period between flowering and picking.

\begin{tabular}{|c|c|c|c|c|c|}
\hline Cultivar & Place & $\bar{D}_{\mathrm{o}}$ & $\bar{D}_{n}$ & Improvement (\%) & $\begin{array}{l}\text { Average } \\
\text { improvement } \\
(\%)\end{array}$ \\
\hline White Transparent & Blangstedgaard & 7.27 & 0.8 & 89 & \\
\hline Cox's Orange Pippin & & 6.33 & 3.3 & 48 & \\
\hline Ingrid Marie & & 5.21 & 0.6 & 89 & \\
\hline Golden Delicious & & 6.19 & 4.7 & 25 & 62.7 \\
\hline White Transparent & Wageningen & 5.2 & 2.0 & 62 & \\
\hline Cox's Orange Pippin & & 7.4 & 5.2 & 30 & \\
\hline Lombarts Calville & & 3.4 & 2.7 & 21 & \\
\hline Schone van Boskoop & & 5.1 & 4.4 & 14 & \\
\hline Jonathan & & 2.2 & 2.2 & 0 & 19.1 \\
\hline Golden Delicious & & 5.1 & 5.2 & -2 & \\
\hline White Transparent & Wilhelminadorp & 5.2 & 7.2 & -38 & \\
\hline James Grieve & & 6.7 & 5.3 & 21 & \\
\hline Cox's Orange Pippin & & 4.3 & 3.7 & 14 & \\
\hline Lombarts Calville & & 1.3 & 2.6 & -100 & \\
\hline Schone van Boskoop & & 9.4 & 9.1 & 3 & \\
\hline Jonathan & & 9.5 & 7.6 & 20 & \\
\hline Golden Delicious & & 7.0 & 6.8 & 3 & \\
\hline Jonagold & & 9.1 & 9.5 & -3 & \\
\hline Gloster & & 6.4 & 6.5 & -2 & \\
\hline Granny Smith & & 9.4 & 3.6 & 62 & -1.2 \\
\hline James Grieve & Bavendorf & 8.2 & 7 & 15 & \\
\hline Cox's Orange Pippin & & 5.0 & 4.8 & 4 & \\
\hline Schone van Boskoop & & 5.0 & 5.2 & -4 & \\
\hline Jonathan & & 3.7 & 3.6 & 3 & \\
\hline Golden Delicious & & 3.5 & 3.9 & -11 & \\
\hline Jonagold & & 8.2 & 5.2 & 37 & \\
\hline Gloster & & 6.5 & 4.6 & 29 & \\
\hline Granny Smith & & 6.4 & 4.3 & 33 & 13.3 \\
\hline
\end{tabular}


relate with a low number of years considered. Improvement percentages are highest in the north: the nearer to the border of production possibilities, the higher the percentages. Again results for Wilhelminadorp do not fit in well.

\section{Acknowledgement}

P. H. van Ewijk (Department of Mathematics, Wageningen Agricultural University) designed the mathematical model and assisted with the computer program. E. Heuvelink (Department of Horticulture, Agricultural University, Wageningen) improved this program. Parts of the discussion were prediscussed with him and some of his ideas were so introduced into the discussion. R. P. M. Buiskool made all the calculations. Data on flowering and picking of apples were provided by:

- Institute of Pomology, Årslev, Denmark;

- Laboratorium voor Tuinbouwplantenteelt, P.O. Box 30, Wageningen, Netherlands;

- Proefstation voor de Fruitteelt, Wilhelminadorp, Netherlands;

- Versuchstation für Intensivkulturen und Agrarökologie, Bavendorf, Ravensburg, BRD.

Climatic data were provided by:

- Jordbuysmeteorologisk Tjemeste, Foulum, Ørum Sønderlyng, Denmark.

- Deutscher Wetterdienst, Zentralamt, Offenbach/Main, BRD.

\section{References}

Beattie, B. B. \& R. R. W. Folley, 1978. Production variability in apple crops II. The long term behaviour of english crops. Scientia Horticulturae 8: 325-332.

Blanpied, G. D., 1960. Guide used in determining maturity as an aid to picking and the relative merit of each method. Proceedings of the Annual Meeting of the New York State Horticultural Society p. 177184.

Fisher, D. V., 1962. Heat units and number of days required to mature some pome and stone fruits in various areas of North America. Proceedings of the American Society for Horticultural Science 80: $141-124$

Jackson, J. E. \& P. J. C. Hamer, 1980. The courses of year to year variation in the average yield of Cox's Orange Pippin apple in England. Journal of Horticulture Science 55: 149-156.

Kronenberg, H. G., 1983. Relationships between temperatures and blooming dates of apple trees. $\mathrm{Ne}$ therlands Journal of Agricultural Science 31: 259-267.

Landsberg, J. J., 1979. Limits to apple yields imposed by weather. In: 75 th anniversary meeting of the association of applied biologists, Reading, UK, $75 \mathrm{pp}$.

Sprenger, A. M., 1948. Handbook on fruit growing (in Dutch), p. 285-287. Tjeenk Willink, Zwolle.

Wellensiek, S. J. \& J. Doorenbos, 1956. Principles of horticulture (in Dutch), p. 156-158. Tjeenk Willink, Haarlem.

Winter, 1981. Lucas' Anleitung zum Obstbau, 30th ed., p. 42-46. Eugen Ulmer, Stuttgart. 